\title{
Strategies to Stimulate Young Female in Engineering
}

\author{
Esther A. Olatundun ${ }^{1 *}$, Folashade E. Archibong ${ }^{2}$, Charles A. Ikutegbe ${ }^{3}$, \\ Enoch D. Ogunmola ${ }^{4}$ and Mayomi O. Alege ${ }^{5}$ \\ ${ }^{1-5}$ Prototype Engineering Development Institute, (National Agency for Science and Engineering \\ Infrastructure, NASENI), Ilesa, Osun State, 233036, Nigeria
}

Tel: +2348035739783

*Corresponding e-mail: estherolatundun10gmail.com

\begin{abstract}
Even though women are working in engineering and scientific fields, the engineering discipline is still seen as a male-dominated sector globally. They have traditionally been underrepresented in the field of engineering. Organizations like the Society of Women Engineers (SWE) and Association of Professional Women Engineers of Nigeria (APWEN) and others alike, host events and conferences to provide guidance, training and support for young females hoping to hone their skills and advance their careers in the engineering sector. However, the perception and participation of female students in science related courses which serve as a fundamental basis for engineering has been very low. This paper adopts the strategic-implementation principle of 'catch them young'. The method involves career counseling, talk shows, seminars on engineering practice, award presentation to outstanding female students and organizing extra moral classes. Results from this study revealed that even though the perception and participation of young female students in sciences are low, the adopted method stimulates them in terms of performance in engineering related subjects and thus yield to more female participation in the engineering field. Other benefits are; to provide a forum for promoting sorority amongst female engineers and to create a platform by which women engineers can collaborate with other women in other professions in Nigeria and elsewhere; to stimulate women in achieving professional excellence as engineers and leaders and to expand the image of the engineering profession as a positive force in improving the quality of life.
\end{abstract}

Keyword: Globally, Strategic-implementation, Perception, Participation.

\section{INTRODUCTION}

Evidence of gender gap in the trend and pattern of enrollment in Nigerian universities has been observed by different researchers (Imhabekhai, 2003; Makhubu, 1998; Oke, 2000; Owolabi, 2001; Ezeliora and Ezeokana, 2010). The turnout of graduates in Nigerian Universities, according to NUC's report on University annual review, showed that from 2001-2005, males who obtained Master's degree were 44,337 (72.79\%) while females were 16,567 (27.20\%). For graduates with doctoral degrees for the same period, males were 2,587 (64.01\%) and females were $798(23.57 \%)$. The participation of women in science and technology education has been and is still low around the world (Kishore, 2008; McCarthy, 2003; Ellis, 2003). Generally, women are underrepresented in almost every area of recognized scientific activity (Kishore, 2008). The females mostly subscribe to social sciences, arts and humanity courses and those that enroll into science are taken as gifted ones. This scenario is not only obtainable in Nigeria (Agu and Omenyi, 2013). At the higher education level in both industrialized and developing countries, women tend to cluster in areas of study which lead to traditional female careers of teaching, nursing and others. Gender parity in universities is a very vital and significant issue because the key to every nation's social, political and economic growth and development lies in the optimal participation of the citizenry in nation building. If basic education of women has produced unequalled socio-economic benefits at the family and community levels (Bunyi, 2004), the university education will enable a nation to leap forth in social, political and economic growth. 


\section{Why Few Women in Engineering?}

According to Aderemi et al. (2013), the number of women in tertiary level science and technology education and professions is low around the world. In 1992 Japanese women made up less than 8\% of scientists and engineers in institutions. Among engineering specialists in the United States (U.S), chemical and metallurgical/metals were the only two occupations in which women were more highly represented than the overall percent of total women engineers. Women made up $17 \%$ of all industrial engineers, $12 \%$ of metallurgical/metal engineers and $11.5 \%$ of chemical engineers. Among all other engineering specialists aerospace, mining, petroleum, nuclear, agriculture, civil, electrical or electronic, mechanical, marine, or naval architects - women represented fewer than $11 \%$. Also, three out of every ten computer systems analysts, engineers and scientists were women. Colwell (2005), in a study on doctorate degrees earned in the United States by women, reported a divergence among the disciplines. In the physical sciences and mathematics, women earned fewer than $20 \%$. In engineering, they received a little over $10 \%$ of Ph.Ds.

Nguyen and Pudlowski (2012) identified some factors that deter women from studying engineering. Such factors include lack of developed confidence to work in such a male-oriented environment; psychological nature whereby women are taught to think they do not possess the essential qualities and skills to become engineers and technologists; the design of engineering curricula to suit the needs of male students, as few girls studying engineering admitted that they were slightly handicapped due to less physical strength when working in some of the workshops, among other factors.

Other researchers have reported that social factors such as socializers and cultural milieu could affect females' enrolment in mathematics. That is, the attitudes and behavious of parents, teachers, counselors and peers have consequences on female enrolment choices in Mathematics (AAUW, 1992; Leedy et al., 2003). Research findings also indicate that these social groups think that males will outshine females in subjects such as high school calculus, and as a result, less encouragement is given to females in the pursuit of mathematics-related courses (Paa and MacWhirter, 2000; Hanna, 2003).

\subsection{Problem Statement}

Technological advancement and industrialization of any country depends on the quality and number of engineers and scientists. Unfortunately, despite all the steps taken in the past to increase the number of engineers, shortages observed are still above $50 \%$ (Badekale, 2003). The shortages remarkably persist even in universities and polytechnics charged with manpower production. Deficits also exist in intermediate technical manpower needed to support engineers (Badekale, 2003). In fact, as found by Oladapo (1983), constraints to technical development lie more with the intermediate category of technicians and craftsmen as with the professional engineers. These shortages may be linked to the fact that fewer number of females, who represent over $50 \%$ in the general population, are in the engineering profession. This underrepresentation of females in engineering professions is traceable to low enrolment of female students into engineering disciplines in the universities and polytechnics. Therefore, a sure way to rapid technological advancement in Nigeria is active participation of more females in engineering profession. Thus, this paper tends to formulate strategies for stimulating young females in engineering.

\section{METHODOLOGY}

The study made use of descriptive survey research design. The design was suitable for the study since the data were collected through questionnaire from Senior Secondary School (SSS) II and SSSIII students to determine the factors that affect young female in engineering right from secondary schools.

\subsection{Areas of Survey}

The study was carried out in Osun State of Nigeria, comprising two (2) educational zones. The zones are Ile-Ife and Ilesa. The population for this study comprised of all SSII and SSIII students in selected secondary schools in Osun State that are offering Science subjects.

\subsection{Techniques of Study}

The sampling technique adopted in this study is the simple random sampling. This is achieved through the application of table of random numbers. Samples of five (5) different secondary schools were randomly chosen from the study areas. The level of students chosen were SSSII and SSSIII. This is because it was perceived that the students have been more exposed to the study of some of the Science subjects. Thus, a total of 253 students were chosen as the sample size. 


\subsection{Method of Data Analysis}

The instrument used was a structured questionnaire to collect data for the study. The data generated from the respondents were analyzed using descriptive statistic. Frequency and percentage were also used to determine the strategy to stimulate young female students in engineering. The research questions asked were the following:

i) Is there any relationship between having engineers as parents and the choice of engineering as a discipline?

ii) Do female students' interest and performance in Mathematics affect their choice of engineering as a course of study?

iii) Do female students' interest and performance in Science subjects affect their choice of engineering as a profession?

iv) What is the relationship between watching scientific documentary on T. V., well equipped science laboratory and organizing quiz competition or exhibition or debates and female students' choice of engineering as a discipline?

v) If female students are motivated by socializers, will they be willing to take up engineering as a course of study?

vi) Is there any awareness by professional engineers to enlighten and encourage the female students to study engineering?

\section{RESULTS AND DISCUSSION}

Results obtained based on the questionnaire administered and respondent views are presented in a tabular form as shown in Tables 1 to 3 .

Table 1 shows that Female has $100 \%$ of the respondents while $0 \%$ goes for the male. This implies that this study focused majorly on female students only.

Table 1: Sex distribution of Respondents

\begin{tabular}{lcc}
\hline Sex & Frequency $(\mathbf{F})$ & Percentage $(\%)$ \\
\hline Female & 253 & 100 \\
Male & 0 & 0 \\
Total & 253 & 100 \\
\hline
\end{tabular}

Table 2 shows that $91.70 \%$ of the respondents are less than 16 years, while $7.12 \%$ are above 16 years and $1.19 \%$ are invalid. This implies that the majority of the students are still very young. One can deduce that with this, the teaching and learning of Science subjects and Mathematics would be more effective for the study of engineering.

Table 2: Age distribution of Respondents

\begin{tabular}{lcc}
\hline Age Range (Years) & Frequency $(\mathbf{F})$ & Percentage $(\%)$ \\
\hline$<$ 16years & 232 & 91.70 \\
$>$ 16years & 18 & 7.12 \\
Nil & 3 & 1.19 \\
Total & 253 & 100 \\
\hline
\end{tabular}

From Table 3 below, 20 of the female students representing 7.91\% have parent(s) that are engineer(s) while 233 of them representing $92.09 \%$ have parents that are not engineers. This could be a very strong factor that can influence the female students in the study of engineering.

Table 3: Respondents' Responses to Items on the Questionnaire

\begin{tabular}{|l|c|c|c|c|c|c|}
\hline \multirow{2}{*}{ QUESTION ITEMS } & \multicolumn{7}{|c|}{ RESPONSES } \\
\cline { 2 - 7 } & YES & NO & $\begin{array}{l}\text { EXCELLENT/ } \\
\text { AVERAFE }\end{array}$ & POOR & NIL & TOTAL \\
\hline Are your parent(s) engineer? & $\begin{array}{c}20 \\
(7.91 \%)\end{array}$ & $\begin{array}{c}233 \\
(90.09 \%)\end{array}$ & - & - & - & 253 \\
\hline $\begin{array}{l}\text { Do you have interest } \\
\text { in Mathematics? }\end{array}$ & $\begin{array}{c}218 \\
(86.17 \%)\end{array}$ & $\begin{array}{c}35 \\
(13.83 \%)\end{array}$ & - & - & - & 253 \\
\hline Performance in Mathematics & - & - & $\begin{array}{c}239 \\
(94.47 \%)\end{array}$ & $\begin{array}{c}11 \\
(4.35 \%)\end{array}$ & $\begin{array}{c}(1.19 \%) \\
2\end{array}$ \\
\hline
\end{tabular}


International Journal of Engineering Research And Advanced Technology, Vol.5, Issue 6, June-2019

\begin{tabular}{|c|c|c|c|c|c|c|}
\hline $\begin{array}{l}\text { Do you have interest in Science } \\
\text { subjects? }\end{array}$ & $\begin{array}{c}203 \\
(80.24 \%)\end{array}$ & $\begin{array}{c}50 \\
(19.76 \%)\end{array}$ & - & - & - & 253 \\
\hline Performance in Science subjects? & - & - & $\begin{array}{c}241 \\
(95.26 \%)\end{array}$ & $\begin{array}{c}8 \\
(3.16 \%)\end{array}$ & $\begin{array}{c}4 \\
(1.58 \%)\end{array}$ & \\
\hline $\begin{array}{l}\text { Do you like watching scientific } \\
\text { documentaries on T. V.? }\end{array}$ & $\begin{array}{c}193 \\
(76.28 \%)\end{array}$ & $\begin{array}{c}56 \\
(22.13 \%)\end{array}$ & - & - & $\begin{array}{c}4 \\
(1.58 \%)\end{array}$ & 253 \\
\hline $\begin{array}{l}\text { Any quiz competition, exhibition } \\
\text { or debates in your school? }\end{array}$ & $\begin{array}{c}208 \\
(82.21 \%)\end{array}$ & $\begin{array}{c}42 \\
(16.60 \%)\end{array}$ & - & - & $\begin{array}{c}3 \\
(1.19 \%)\end{array}$ & 253 \\
\hline $\begin{array}{l}\text { Rate your Mathematics, Physics } \\
\text { and Chemistry teachers. }\end{array}$ & - & - & $\begin{array}{c}246 \\
(97.23 \%)\end{array}$ & $\begin{array}{c}2 \\
(0.79 \%)\end{array}$ & $\begin{array}{c}5 \\
(1.98 \%)\end{array}$ & 253 \\
\hline $\begin{array}{l}\text { Do you have Science Laboratory in } \\
\text { your school? }\end{array}$ & $\begin{array}{c}250 \\
(98.81 \%)\end{array}$ & $\begin{array}{c}2 \\
(0.79 \%)\end{array}$ & - & - & $\begin{array}{c}1 \\
(0.40 \%)\end{array}$ & 253 \\
\hline $\begin{array}{l}\text { Do you know any female } \\
\text { engineer? }\end{array}$ & $\begin{array}{c}101 \\
(39.92 \%)\end{array}$ & $\begin{array}{c}152 \\
(60.08 \%)\end{array}$ & - & - & - & 253 \\
\hline $\begin{array}{l}\text { Is anybody motivating you to study } \\
\text { engineering? }\end{array}$ & $\begin{array}{c}49 \\
(19.37 \%)\end{array}$ & $\begin{array}{c}198 \\
(78.26 \%)\end{array}$ & - & - & $\begin{array}{c}6 \\
(2.37 \%)\end{array}$ & 253 \\
\hline Do you wish to study engineering? & $\begin{array}{c}38 \\
(15.02 \%)\end{array}$ & $\begin{array}{c}215 \\
(84.98 \%)\end{array}$ & - & - & & 253 \\
\hline
\end{tabular}

Source: Field Survey, 2014

Table 3 shows that $86.17 \%$ of the respondents have interest in Mathematics, while $13.83 \%$ said no. This indicates that if there is enough awareness, (since they have interest in Mathematics) the students will perform better in engineering.

From Table 3, 239 of the female students representing 94.47\% have excellent and average performance in Mathematics while 11 female students representing $4.35 \%$ have poor performance and 3 students representing $1.19 \%$ are invalid.

Table 3 shows that $80.24 \%$ of the respondents have interest in Science subjects while $19.76 \%$ said no. This reveals that if there are motivators to sensitize them to the study of engineering, they will be there and perform better.

From Table 3, 241 of the female students representing 95.26\% have excellent and average performance in Science subjects while 8 female students representing $3.16 \%$ have poor performance and 4 of them representing $1.58 \%$ are invalid.

Table 3 shows that $76.28 \%$ of the Science female students like to watch scientific documentary on $\mathrm{T}$. V. This supposed to be a source of encouragement to them while $22.13 \%$ do not like watching it and $1.58 \%$ are invalid.

From Table 3, 208 of the female students representing $82.21 \%$ have schools that encourage Science learning by organizing quiz competition or exhibition or debates while $16.60 \%$ said NO and $1.19 \%$ are invalid.

From Table 13, 246 of the female students representing 97.23\% have excellent and average teachers in Mathematics, physics and chemistry while $0.79 \%$ have poor teachers and $1.98 \%$ are invalid.

Table 3 shows that $98.81 \%$ of the Science female students have well equipped Science Laboratory in their schools to facilitate better learning environment while $0.79 \%$ said $\mathrm{NO}$ and $0.40 \%$ refused to feed any.

Table 3 shows that $39.92 \%$ of the respondents agreed that they know female engineers while $60.08 \%$ disagreed. This alone is enough to discourage some of the female students to study engineering. 
When the question "is anybody motivating you to study engineering" was asked according to Table 3, 19.37\% of the respondents agreed that they have motivator(s) or mentor(s) that they can look upon while $78.26 \%$ said NO and 2.37 refused to answer YES or NO to the question. This indicates that majority of the female students do not have a motivator to stimulate them to study engineering.

Table 3, revealed that 38 females representing $15.02 \%$ agreed to study engineering while 215 females representing $84.98 \%$ are not ready to study engineering.

\subsection{Summary of Findings}

\subsubsection{Research question (i)}

The findings of the study revealed that parents that are professional engineers can influence their children especially the females to study engineering, if they are successful. However, there is a relationship between having engineers as parents and the choice of engineering as a discipline (see Table 3). Whereas some illiterate parents do not consider any subject/course important than the other and students from such parents are hardly influenced to choose any particular course of study. 20 female students out of 253 have their parents to be engineers and 6 females out of the 20 will like to study engineering. This $30 \%$ may be as a result of parental influence. This is a good result.

\subsubsection{Research question (ii)}

From Table 3, $86.17 \%$ are interested in Mathematics and $94.47 \%$ have excellent/Average performance in Mathematics, still they do not want to study engineering. This may be due to lack of awareness, encouragement and motivation from the socializers. This indicates that students' interest and performance do not affect their choice of engineering.

\subsubsection{Research question (iii)}

It has been found out from Table 3 that $80.24 \%$ have interest and $95.26 \%$ female students' performance is excellent/Average, which supposed to be a very good indicator for their choice of engineering as a course of study. On the contrary, very few of them want to study engineering. This may be due also to lack of motivation and awareness in most secondary schools.

\subsubsection{Research question (iv)}

From the research question asked "is there any relationship between watching scientific documentary on T. V., well equipped science laboratory and organizing quiz competition or exhibition or debates and female students' choice of engineering as a discipline?". 76.28\% said they like watching scientific documentary on T. V., $98.81 \%$ have well equipped science laboratory and $82.21 \%$ said their schools usually organize quiz competition or exhibition or debates. These are very good results, still the number of female students that want to study engineering is relatively low. This means that there is no relationship between watching scientific documentary on T. V., well equipped science laboratory and organizing quiz competition or exhibition or debates and female students' choice of engineering as a discipline.

\subsubsection{Research question ( $v$ )}

If female students are motivated by socializers, will they be willing to take up engineering as a course of study? 101 out of 253 female students representing 39.92\% said they know female engineers and 49 out of 253 female students representing $19.37 \%$ have motivators or mentors who can encourage them to study engineering, also 8 of them have their parents as their mentor. Therefore, 41 out of 253 got motivation from people that are not their parents but are their relations and friends. The motivation they got from people is very low, which means if we have more socializers that can motivate them the more in secondary school levels, then there will be more female students in engineering.

\subsubsection{Research question (vi)}

Is there any awareness by professional engineers to enlighten and encourage the female students to study engineering? Research questions $\mathrm{i}$ to $\mathrm{v}$ have done justice to this question. Research question $\mathrm{v}$ revealed that the motivators are very few in number, despite that, the few ones are not doing the work of motivation and encouragement very well. Even from the questionnaires that were administered, only 38 out of 253 female students representing $15.02 \%$ are willing to study engineering and this is very low. So we need more female students in the field of engineering. 


\section{CONCLUSION}

It has been found that increasing the enrolment of women in engineering depends on the manner in which the message about engineering is conveyed to students at the secondary school level of education, teachers need to be more responsive. They need to be more sympathetic, supportive and encouraging, for more female students to study engineering. There is need to do more assignments/ work so as to raise female students' awareness in engineering. At the tertiary level, more effort needs to be taken in designing engineering curricula to include the humanities and non-technical content and to remove those aspects of curricula that deter women from undertaking engineering courses. Engineering departments should devise more aggressive strategies to attract female students to engineering courses, for instance by organizing special seminars for secondary school students. Such seminars can provide students with the opportunity of learning about a particular branch of engineering, making themselves familiar with the technologies and processes used, as well as research achievements. Academics must go out to young students with a message about what engineering involves and why women should become engineers, particularly as women can bring a different dimension, quality and skill to engineering. Generally, more studies need to be devised and carried out on the existing population of female engineering students to learn about their personal experiences. This could assist in finding more effective ways to attract a greater number of women to engineering in the future. Organizations like the Society of Women Engineers (SWE) and Association of Professional Women Engineers of Nigeria (APWEN), host events and conferences to provide guidance, training and support for those hoping to hone their skills and advance their careers in engineering. Motivation, passion and an opportunistic attitude will help women get ahead in their engineering careers. A good example is that of Association of Professional Women Engineers of Nigeria (APWEN), where there will be visitation to schools to encourage engineering studies and practice amongst female Nigerians with awards and prizes, also, to provide a forum for promoting sorority amongst female engineers and to create a platform by which women engineers can collaborate with other women in other professions in Nigeria and elsewhere.

\section{RECOMMENDATIONS}

It is recommended that:

i) Teachers, students, parents, school administrators and indeed the entire public should have attitude in favour of science learning. It is not for the poor or down trodden, it is for people whose talent and abilities are in the area of manipulative skills leading to technology transformation of Nigerian society.

ii) Parents and relatives should stop discouraging student's ambition towards Science courses which will finally lead to the study of engineering in higher institutions as a career.

iii) Also, there is need for awareness right from secondary schools. The absence of guidance and counseling in secondary schools should be looked into as well. This is because most schools do not have guidance and counseling unit.

\section{REFERENCES}

1. Aderemi, H. O., Hassan, O. M., Siyanbola, W. O. and Taiwo, K. (2013). Trends in enrolment, graduation and staffing of science and technology education in Nigeria tertiary institutions: A gender participation perspective. Academic Journals. 8(21): 2011-2020.

2. (Agu, N. N and Omenyi, A. S. (2013). Gender enrolment status in higher education courses: A situation assessment and analysis of a south eastern federal university. Journal of Emerging Trends in Educational Research and Policy Studies. 4(3): 517-524.

3. American Association of University Women (AAUW) (1992). How schools shortcharge girls. Wshington DC: American Association of University Women Education Foundation.

4. Badekale, A. J. (2003). Women in engineering in Nigeria: Towards improved policy initiatives and increased female participation. ATPS Working Paper Series No. 37

5. Bunyi, G. W. (2004). Gender disparities in higher education in Kenya: Nature, extent and the way forward. The African Symposium, 14(1).

6. Cowell, R. R (2005). How do we achieve systematic institutional change? Association of Women in Science (AWIS) Conference on Women Scientists and Engineers. Smith College, New Hampton, Massachusetts, June 24, 2005. Available at http://www.awis.org/conference/colwellspeech.html

7. Ellis, P, (2003). Women in science-based employment: what makes the difference? Bull. Sci. Technol. Soc. 23(1):10-16 
8. Ezeliora B. and Ezeokana, J. O (2010). Inhibiting influences of some traditional practices in the home on girl-child's scientific development. International Journal of FAWE, Nigeria 2(1):31-42.

9. Imhabekhai, C. I. (2003). Analysis of female participation in university education at the University of Benin in Nigeria. Journal of Educational Foundations and Management. 3(1): 101-109

10. Kishore, L. (2008). Girls, women in science and technology education. Merinews online publication.

11. Leedy, G., Lalonde, D. and Runk, K. (2003). Gender equity in mathematics: Beliefs of students, parents and teachers. School Science and Mathematics, 103(6): 285-292.

12. Makhubu, L. P. (1998). The right to higher education and equal opportunity particularly for women: the challenges of our time. In J. Shabam (Ed.). Higher Education in Africa: Achievements, Challenges and Prospects.

13. McCarthy, G. (2003). Where are the women in Australian Science. Australian Science and Technology Heritage Center. Available online at http://www.austehc.unimelb.edu.au/wisa/wisaabout.html

14. Nguyen, D. Q. and Pudlowski, Z. J. (2012). Enrolment of women in engineering and technology degree programmes in Australia. Third WIETE Annual Conference on Engineering and Technology Education, Pattaya, Thailand, 6-10 February.

15. Oke, M. (2000). Gender gap and access to secondary school science education: The way forward. WAEC monthly Seminar Paper, 2, 103-113.

16. Oladapo, I. O. (1983). 'Manpower requirements for engineering and technological development in Nigeria' in Management in Nigeria, November/December pp. 6-15.

17. Owolabi, J. (2001). Towards improving female participation in science, technology and teacher education. Journal of Lagos State University, Institute of Education, 2, 123-128.

18. Paa, H. and MacWhirter, E. (2000). Perceived influences on high school students' current career expectations. Career Development Quarterly, 49(1): 29-44. 